\title{
The Use of Cacao Peels Extract (Theobrema Cacao) as the Corrosion Inhibitor on Steel Layers Electrodeposition
}

\author{
Silva Azaria Mahaputri ${ }^{1}$, Dahyunir Dahlan ${ }^{1}$ and Yuli Yetri ${ }^{2 *}$ \\ ${ }^{1}$ Physics Department, Andalas University, Indonesia \\ ${ }^{2}$ State Polytechnic of Padang, Kampus Limau Manis Padang, Indonesia
}

Submission: May 04, 2018; Published: May 21, 2018

*Corresponding author: Yuli Yetri, State Polytechnic of Padang, Kampus Limau Manis Padang, 25163, Indonesia, Email: yuliyetriyetri@gmail.com

\begin{abstract}
An electro deposition of $\mathrm{Ni}$ film has been carried on steel substrat using $0,5 \mathrm{M} \mathrm{NiSO} \mathrm{N}_{4} \cdot 6 \mathrm{H}_{2} \mathrm{O}$ solutions with the addition of cacao peels extract inhibitor. This study performed electro depositon variation of time and inhibitor concentration variation of cacao peels extract were performed with the tensile of $3 \mathrm{~V} 2 \mathrm{~mA}$. There was morphology difference occurred on steel before and after being electrodeposited. The adding of extract cacao peels inhibitor influenced morphology as well and minimized the occurence of corrosion on steel surface. Referred to characterization result in order to see morphology using optical microscope and SEM, the result was better on $1 \%$ inhibitor concentration with 25 minutes electro deposition time. Steel surface was seen more evenly and finer. Seeing it through XRD result, the constructed peaks were thinner by adding cacao peels extract inhibitor. The inhibition efficiency result of corrosion rate measurement using potentiodynamic polarization resulted $16.8 \%$ of $\% \mathrm{IE}$ for $1 \%$ concentration, and $66.88 \%$ for $1.5 \%$ concentration. The more inhibitor concentration increased, the more and the better the compounds acted as corrosion inhibitor. The weight loss method measurement obtained an increase on corrosion rate and inhibition efficiency and more cacao peels extract inhibitor concentration.
\end{abstract}

Keywords: Steel; Electrodeposition; $\mathrm{NiSO}^{4}$; Cacao peels extract; Inhibitor

\section{Introduction}

Steels are utilized in industry world because of its strength, easily forged and oxidized, good conductivity like iron, copper, steel, zinc, and aluminium. One of applications in using the steel is through off shore piping, bridge construction, building, framework of a vehicle. However, it is easily oxidized as it is directly interacted with its surrounding and causes corrosion. Corrosion are not only hazardous for human and environment, but also economically causes considerable costs and huge loss [1] even threating human safety $[2,3]$. Corrosion is a destructive process as a result of chemical reaction between metal or alloy with its environment $[4,5]$. Hence, corrosion on metal is a reduction reaction process and chemical oxidation or electrochemical causing electron transfer from steel to environment, so metal oxidation number changed from zero to positively charged [3].

In order to prevent the metal from destruction and to have good performance, several techniques have been applied in minimizing the corrosion attack, by cleaning, painting or coating its surface. The more efficient and easier way to coat the steel surface is by using the electro deposition method. Electrodeposition is coating the steel surface with other metals using electrolyte solution
[2], which is $\mathrm{NiSO}_{4}$. Another way taken for coating is by adding inhibitor solution, where this inhibitor is aimed to slow down its corrosion rate. There are many inibitors can be perceived like organic inhibitor and inorganic one. Inorganic inhibitor is more harmful as it is included into chemical compound and relatively high-cost. Meanwhile inorganic inhibitor can be obtained from nature, relatively low-cost, and easy to use. Therefore people can make use of organic compounds found in nature as inhibitor, where the chosen natural products are those containing tannin substance, and preventing corrotion process occured.

Moreover, several researches have been conducted using plants like pinus, gambeer and coffee extract [5], pineapple extract inhibitor [6], paniculata extract [7], red peanut extract inhibitor [8], aningeria robusta extract [9], camellia sinensis extract [10], soursop leaves extract [11], red spinach leaves extract [12].

Corrosion inhibition study and mild steel mechanical properties recovery using cacao (Theobroma cacao) peels extract in acid media [3] have been investigated. Likewise, the study on eco-friendly inhibitor corrosion behaviour of cacao peels 
extract for mild steel in $\mathrm{NaCl} 1.5 \mathrm{M}$ [13] corrosive media has been investigated. Thus, this study concerns on making use of cacao peels extract as inhibitor which is going to be coated onto steel surface using electro deposition method by adding $\mathrm{NiSO}_{4}$ substance.

\section{Materials and Method}

\section{The making of electrolyte solution}

The electrolyte used is $\mathrm{NiSO}_{4}$ and made by weighting 20 grams $\mathrm{NiSO}_{4}$, then adding 3 grams $\mathrm{H}_{3} \mathrm{BO}_{3}$, and dissolved in $200 \mathrm{~mL}$ aqudest. After that, this solution is stirred using magnetic stirrer for 30 minutes at room temperature.

\section{The making of cacao peels extract}

Obtained cacao peels extract is thinly sliced and wind dried for 14 days. Once it is dried, grinded using the grinding machine. Then grinded cacao peels extract is macerated using $70 \%$ ethanol for 5 days, filtered and concentrated by using evapolator vacuum. The result obtained is concentrated extract of cacao peels. This concentrated extract continuing the process to be as primary solution and further dissolved into varied concentration of $0 \%$, $0.5 \%, 1 \%, 1,5 \%, 2 \%$ and $2,5 \%$.

\section{Corrotion rate measurement}

Potentio-dynamic Polarization: It is a method in determining metal corrosion property based on potential connection, and anodic and cathodic current. Polarization is reaction potential deviation of its equilibrium potential. It is either in the form of anodic, if the anodic proces in cathode is accelerated by changing potential in positive way, or in the form of cathodic polarization, if the cathodic process is accelerated by transfering respective potential in negative way [4].

Applied potential line (potential-greater) toward current density is commonly known as Tafel plot. The slope of Tafel, corrosion potential (Ecorr), and corrosion current density (Icorr) can be indicated using extra polarization way. This Tafel Method provides information on the number of produced corrosion current (Icorr) on steel surface interacting with corrosive solution. Hence, further obtained current value can become performance parameter of a corrosion inhibitor. Inhibition efficiency can be identified with the equation below (1),

$$
\% I E=\frac{I_{\text {unh }}-I_{\text {inh }}}{I_{\text {unh }}} .100
$$

where $I_{\text {unh }}$ is current in the absence of inhibitor, and $I_{\text {inh }}$ is solution current in the presence of inhibitor. The higher the inhibiton efficiency value (\%) of a solution containing particular compound, the better the compound acted as corrosion inhibitor.

Weight loss method: Weight loss method is measuring the weight loss occured on metal before and after being immersed in corrosive solution for particular length of time. Corrosion rate on this method can be decided using the equation below (2) [14].

$$
V=\frac{\Delta}{A}
$$

where $\mathrm{A}$ is cross section area, $\Delta \mathrm{m}$ is weight lost and $\mathrm{t}$ is time. Whereas, inhibition efficiency is determined by using the equation (3) as follow:

$\% I E=\frac{V_{0}-V_{1}}{V_{0}} .100 \%$

Where $V_{0}$ is corrosion rate in the absence of inhibitor and $V_{1}$ is corrotion rate after receiving inhibitor treatment on corrosive media.

\section{Result and Discussion}

\section{Surface Characterization}

Initially surface characterization was recoginized using optical microscope, where the whole result of time difference and cacao peels extract inhibitor concentration were visualized using this microscope. The result of this microscope can be seen in Figure 1.

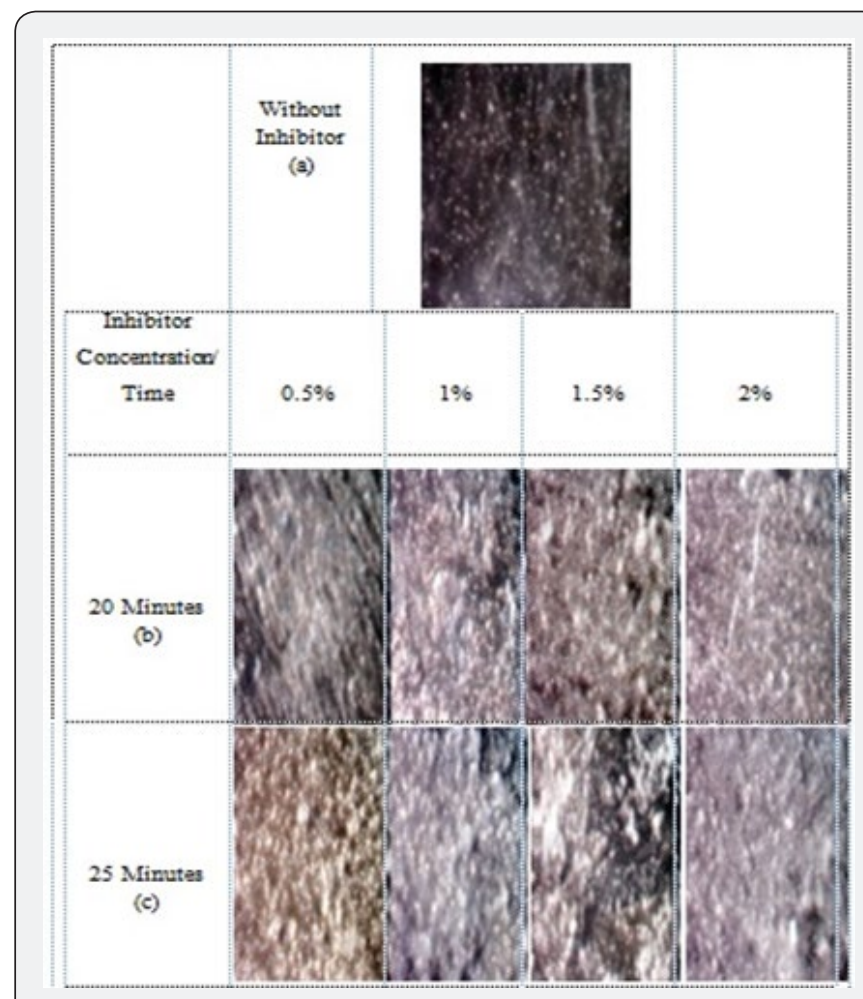

Figure 1: Result of electrodeposited steel with time difference and cacao peels extract inhibitor concentration difference.

The observation result using optical microscope with $100 \mathrm{x}$ magnification, $3 \mathrm{~V}$ voltage and $2 \mathrm{~mA}$ current, showed steel surface yet being electrodeposited and the one electrodeposited by adding inhibitor concentration variation of cacao peels extract inhibitor, and by variying the time.

It could be seen that the implemented variation of time was 20 and 25 minutes with $0.5 \%, 1 \%, 1.5 \%, 2 \%$ on differences of cacao peels extract inhibitor concentration. The result of concentration variation and time variation of the best result was obtained on the time of 25 minutes with $1 \%$ concentration and on 20 minute with $1.5 \%$ concentration. The obtained best result from optical microscope was proceeded to characterization test by using SEM. 


\section{Recent Advances in Petrochemical Science}

\section{SEM}

The next characterization was conducted using SEM, where the sample for this characterization was the best sample from obtained optical microscope result. The sample had fine surface after being electrodeposited by adding $1 \%$ and $1.5 \%$ cacao peels extract inhibitor concentration. SEM result could be seen in Figure 2.

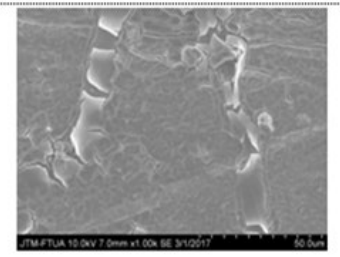

(a)

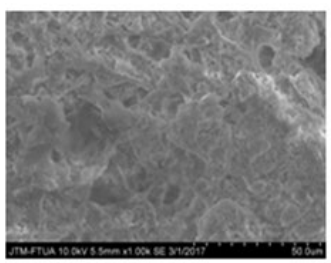

(c)

Figure 2: The result of electrodeposited steel SEM by using $\mathrm{NiSO}_{4}$ with (a) in the absence of inhibitor (b) in the presence of $1 \%$ inhibitor concentration, (c) in the presence of $1.5 \%$ inhibitor concentration, and (d) with $60^{\circ}$ Celcius temperature, with $1 \%$ inhibitor concentration and time for 25 minutes.

Figure 2 shows the presence of layers resulted from electro deposition which can prevent corrosion occured. While Figure 2a shows steel SEM result in the absence of inhibitor addition, seen that steel surface is only coated by $\mathrm{NiSO}_{4}$ solution. Figure $2 \mathrm{~b}$ shows with the addition of $1 \%$ cacao peels extract inhibitor, seen that steel surface is more evenly and finer. Then, Figure $3 \mathrm{c}$ indicates that even though the surface is more even by the adding $1.5 \%$ inhibitor, it is seen rougher as the result of much inhibitor concentration given.

The addition of cacao peels extract on the electro deposition process could minimize corrosion product and holes on steel surface by constructing passive layers on the surface. These layers functioned as barrier on the corrosive ion attack on steel surface, so that the electrochemical reaction starting to slow down and eventually decreasing the corrotion rate [15].

\section{XRD}

The result of XRD on two electrodeposited samples in the absence and in the presence of cacao peels extract inhibitor can be seen in Figure 3. The three samples in Figure 3 demonstrate the two peaks; Fe and Ni peak. Figure 3a is XRD result taken from steel samples without electrodeposited in the beginning. Whereas in Figure $3 \mathrm{~b}$ exhibits some Ni peaks resulted from electro deposition process using $\mathrm{NiSO}_{4}$ solution, where Fe peak covered by Ni peak. However in Figure 3c with the addition of cacao peels extract in electro deposition process, these obtained Ni peaks are forming thin layer in order to minimize the occurence of corrosion.

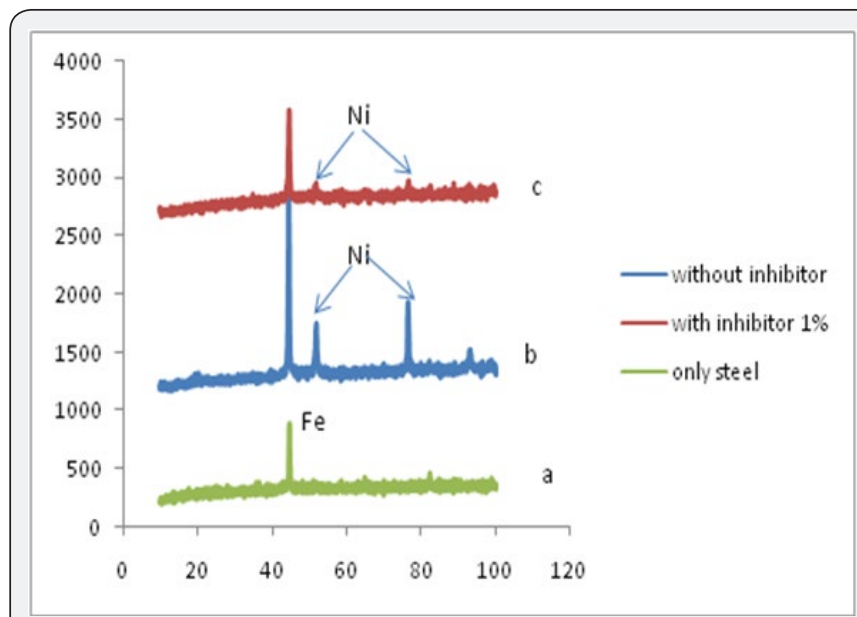

Figure 3: Result of XRD Analysis

\section{Potentio-dynamic polarization method}

Steel polarization curve as the result of $\mathrm{NiSO}_{4}$ electro deposition by adding cacao peels extract inhibitor with concentration differences; $1 \%$ and $1.5 \%$ in $\mathrm{HCl} 1 \mathrm{~N}$ solution and been extra polarized into Tafel line can be seen in Figure 4. The result in Figure 4 indicates that the higher the inhibition efficiency value of solution containing tannin compound, the better the tannin compound acted as corrosion inhibitor. Result of \%IE corrotion parameter as seen in Table 1.

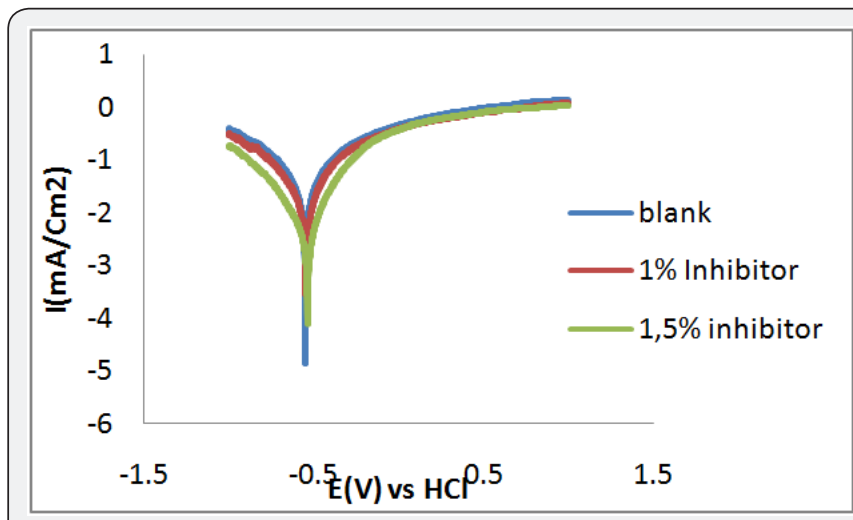

Figure 4: Potential Tafel Line of Steel Polarization resulted from $\mathrm{NiSO}_{4}$ electrodeposition with the addition of cacao peels extract in $\mathrm{HCl} 1 \mathrm{~N}$ solution, and $1 \%$ and $1.5 \%$ concentration variation of cacao peels extract inhibitor.

Table 1: Steel corrosion parameter in $\mathrm{HCl} 1 \mathrm{~N}$ in the absence and in the presence of cacao peels extract inhibitor obtained from polarization measurement.

\begin{tabular}{|c|c|c|c|}
\hline $\begin{array}{c}\text { Concentration } \\
\% \mathbf{~ V / V}\end{array}$ & Icorr & Ecorr & \%EI \\
\hline Blank & 7,58927 & 0.59 & - \\
\hline $1 \%$ & 15,14258 & 0.69 & $16.82 \%$ \\
\hline $1.5 \%$ & 26,92775 & 0.79 & $66.88 \%$ \\
\hline
\end{tabular}




\section{Weight-loss method}

The measurement result of corrosion rate and inhibition efficiency applying weight loss method with the formula (2) and (3) indicated that the addition of cacao peels extract into corrosion medium caused the corrosion rate decreasing, and in the contrary the inhibition efficiency increasing. It was due to the steel surface covered by molecules in cacao peels extract. The cacao peels extract molecules covering metal surface were absorbed onto the respective steel surface forming passive layer protecting steel from active ions attack which was in the acid solution. Formed passive layer derives from oxygen and functional group on cacao peels extract [15]. Figure 5 indicates that the longer the immersion time, the higher the corrosion rate as the longer the immersion takes time, the more weight loss occured [16].

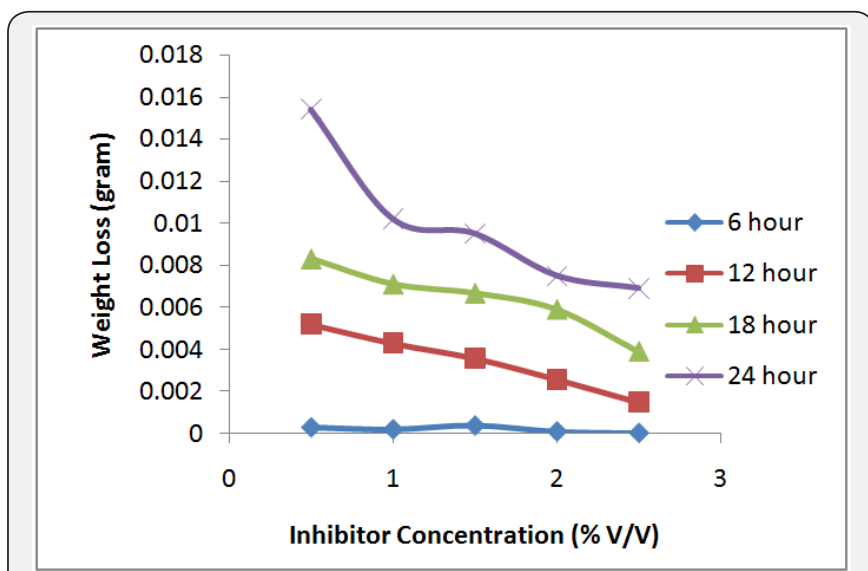

Figure 5: Cacao peels extract inhibitor concentration vs weight loss with immersion time variation.

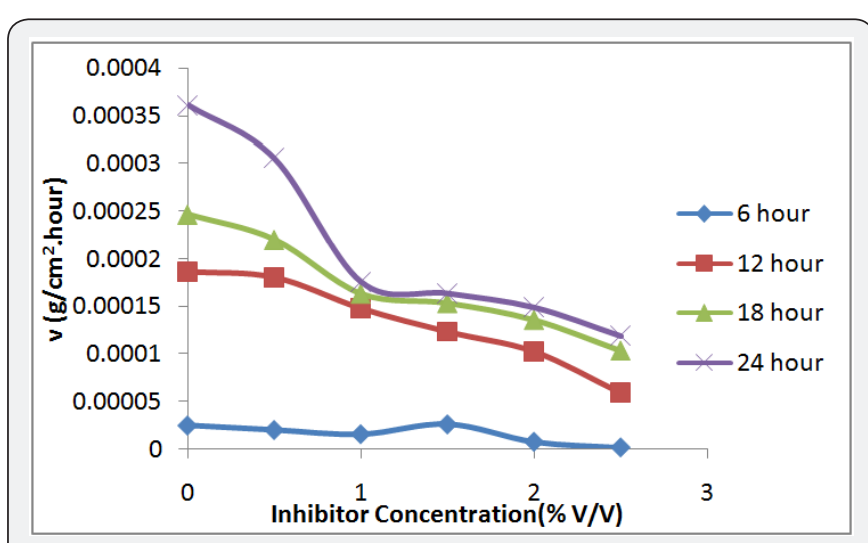

Figure 6: Cacao peels extract concentration vs steel corrosion rate in $\mathrm{HCl} 1 \mathrm{~N}$ with immersion time variation. Immersion time vs steel corrosion rate with inhibitor concentration variation of cacao peels extract.

In Figure 6 can be seen, the effect of the addition of cacao peels extract inhibitor to the corrosion rate, the longer the immersion time causes the increase of corrosion rate and with the addition of inhibitor of cacao peels extract will decrease the corrosion rate. This is because the more inhibitors of cacao peels extract are added, the more cacao peels extract is adsorbed on the steel surface, so that the surface-formed layer can inhibit the corrosive rate attack on the steel surface, so that the corrosion rate of steel can be inhibited $[1,16,17]$. On the other hand, Figure 7 shows that the increase on immersion time causes the more mass loss occured and it stimulates desorption [16].

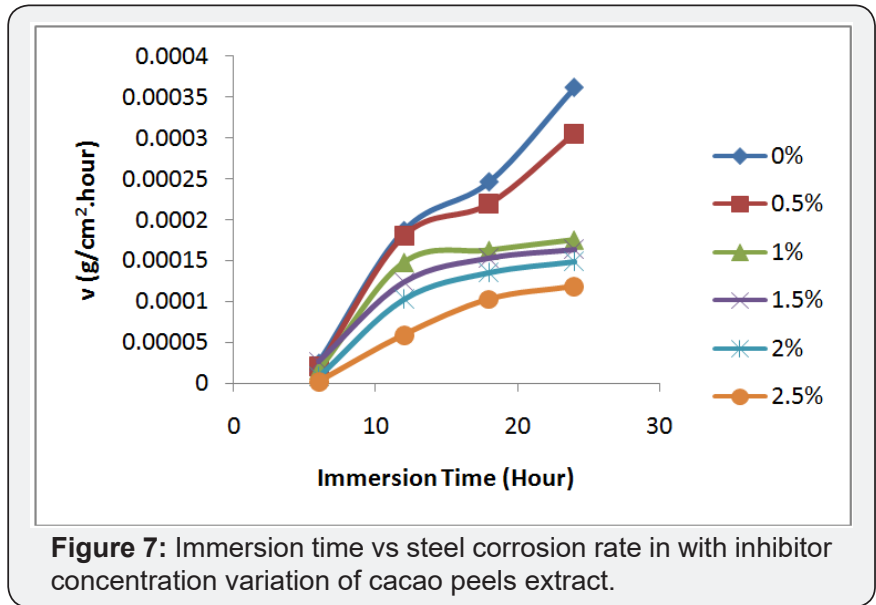

\section{Conclusion}

By using 2 Volt, optimum electro deposition result is obtained through morphology on 25 minutes time and 1\% cacao peels extract inhibitor concentration. Based on characterization result of electrodeposited steel surface, the morphology surface becomes more evenly and finer, and with the absence of porosity on steel sample of electro deposition by adding $1 \%$ cacao peels extract inhibitor.

The corrosion test result shows that inhibition efficiency of cacao peels extract increasing in line with the increase on concentration. Conversely, the corrotion rate decreases in line with the increasing of cacao peels extract inhibitor concentration. Based on potentio-dynamic polarization method, it is known that cacao peels extract inhibitor is in the form of anodic and cathodic.

\section{References}

1. Yetri Y (2015) Corrosion Inhibitir of Mild Steel by Polar Extract of Theobroma cacao Peels in Hydrochloric Acid Solutio. Asian Journal of Chemistry 27(3): 875-881.

2. Agustina E, Dahlan D, Shukri (2013) Structure and Properties of Thin Layer Optics $\mathrm{TiO}_{2}$ (Titanium Dioxide) Generated by Electrodeposition Method. Jurnal Ilmiah Fisika 2(3): 180-185.

3. Rosales BM, Vera R (2012) Oladis Troconis de Rincon and Johan Tidblad, 2012, Atmospheric Corrosion. International Journal of Corrosion, 10: 1-3.

4. Dahlan DI (2009) Electrodeposition of Cu2O Particles by Using Electrolyte Solution Containing Glucopone as Surfactant. Jurnal Ilmiah Fisika 1(2): 18-20.

5. Ekanem UF, Umoren SA, Udousoro SA, Udoh AP (2010) Inhibition of mild steel Corrosion in HCL using Pineapple leaves extract. Journal of Material Sciense 45(20): 5558-5566.

6. Figueira A, Janick (2008) New Products from Theobroma cacao. Speed pulp and pod gum. Advances in Botanical Research 55: 885-892.

7. Jiang T, lim J, Nail J (2001) Three Methods For Thin Film Deposition of Copper With Potential Commercial Aplication. The Solid Films 324: 164-185. 


\section{Recent Advances in Petrochemical Science}

8. Kvedaras V, Vilys J, Ciuplys V (2006) Fatique Strength ChromiumPlated Steel 12(1): 1320-1329.

9. Loto CA (2011) Inhibition effect of tea (Camellia Sinensis) extract on the corrosion of mild steel in dilute sulphuric acid. J Mater Environ Sciens 2(4): 335-344.

10. Mustopo DY (2011) Time Influence Against Thickness and Layer Adhesivity on the Decorative Chrome Chromium Electroplating Process Without the Basic Layers, with Copper and Nickel-Nickel Basic Layers, Thesis, Mechanical Engineering Faculty of Engineering, Sebelas Maret University, Surakarta.

11. Papavinasam S (2006) Evaluation and Selection of Corrosion Inhibitor. In: ( $\left.2^{\text {nd }} e d n\right)$, John Wiley \& Sons, Inc, USA, pp. 1089-1105.

12. Purnomo A (2015) the effect of variation of cocoa fruit skin extract inhibitor concentration on corrosion rate of a53 carbon steel pipe on sea water medium. Journal of ROTOR 8(1): 8-12.

13. Obot IB, Umoren SA, Obiengbedi NO (2011) Corrosion Inhibition and Adsorption behaviour for aluminuim by extract of Anungeria robusta in HCL solutio: Synergistic effect of iodide ions. J mater Environ sciens 2: 60-71.

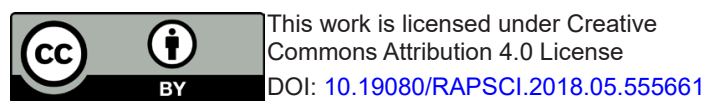

14. Ostovari A, Hoseinieh SM, Peikari M, Shadizadeh SR, Hashemi SJ (2009) Corrosion Inhibitor of mild steel in 1M HCL solution by Henna Extract : A Comparative Study of Inhibition by Henna and Its Contituents (Lawsone, Gallic acid, Glucose and Tanic acid). Corrosion Sciens 51: 1935-1949.

15. Yatiman P (2009) Application of Organic Inhibitors for Corrosion Control of Metals and Alloys, Prosiding Seminar Nasional Penelitian, Pendidikan dan Penerapan MIPA, Fakultas MIPA, Universitas Negeri Yogyakarta, Yogyakarta.

16. Yetri Y (2016) Corrosion Behavior of Environmental Friendly Inhibitor of Theobroma cacao Peels Extract for Mild Steel in $\mathrm{NaCl} 1.5 \mathrm{M}$. Environment Asia 9(1): 45-59.

17. Satahapthy AK, Gunasekaran G, Sahoo SC, Kumar A, Rodriguens PW, et al. (2009) Corrosion Inhibition by Justica Gendarussa Plant Extract in Hydrocholiric acid solution. Corrosion Science 51(12): 2848-2856.

\section{Your next submission with Juniper Publishers will reach you the below assets}

- Quality Editorial service

- Swift Peer Review

- Reprints availability

- E-prints Service

- Manuscript Podcast for convenient understanding

- Global attainment for your research

- Manuscript accessibility in different formats

( Pdf, E-pub, Full Text, Audio)

- Unceasing customer service

Track the below URL for one-step submission https://juniperpublishers.com/online-submission.php 